\title{
Executive Compensation in American Unions
}

June 17, 2011

\author{
Kevin F. Hallock \\ Cornell University and NBER \\ and \\ Felice B. Klein \\ Cornell University
}

We are grateful to David Card, John DiNardo, David Lee, Brian McCall, Thomas Lemieux, two anonymous referees and the editor for very helpful suggestions and to the ILR School at Cornell University for financial support. 


\section{EXECUTIVE COMPENSATION IN AMERICAN UNIONS}

Studying compensation in the nonprofit sector is difficult. In nonprofit organizations, it is not always clear what the objectives of the organization are and, therefore, perhaps even more difficult to consider how to compensate managers than in the for-profit sector. This paper investigates the determinants of executive compensation of leaders of American labor unions. We use panel data on more than 75,000 organization-years of unions from 2000 to 2007 which allows us to examine within union differences over time. We specifically concentrate on two issues of importance to unions - the level of membership and the wages of union members. Both measures are strongly related to the compensation of the leaders of American labor unions, even after controlling for organization size and individual organization fixed-effects. That is, within the same union, higher levels of membership size and average member wage over time are associated with higher levels of pay for union leaders. Additionally, the elasticity of pay with respect to membership for unions is very similar to the elasticity of pay with respect to employees in for-profit firms over the same period.

Kevin F. Hallock

Departments of Labor Economics and Human Resource Studies

256 Ives Hall

ILR School

Cornell University

Ithaca, NY 14853

and NBER

(607) 255-3193

hallock@cornell.edu
Felice B. Klein

Department of Human Resource Studies 158 Ives Hall

ILR School

Cornell University

Ithaca, NY 14853

(607) 351-3937

fbk3@cornell.edu 


\section{Introduction and Motivation}

This paper investigates the determinants and structure of executive compensation of the leaders of American labor unions. There has been considerable research into the determinants of managerial pay in for-profit companies in the United States (e.g. Murphy, 1985; Murphy 1999; Bebchuk and Fried, 2006). However, considerably less attention has been placed on compensation (and executive compensation in particular) in nonprofit organizations. Only recently have authors begun to investigate the compensation of managers in nonprofits (e.g. Oster, 1998; Hallock, 2002) and even made some comparisons between managerial pay in forprofit and nonprofit organizations (Hallock, 2004).

Studying managerial compensation in nonprofit organizations is particularly difficult since the goals and objectives of these organizations are less clear than they are in the for-profit sector. While many argue that for-profit companies are organized principally to create returns for shareholders, the objectives of nonprofits may differ quite dramatically. One issue that comes out of previous research on compensation in nonprofits is the need to focus attention on particular industries within the nonprofit sector since the objectives of nonprofits may dramatically differ across industries (e.g. Ehrenberg, Cheslock, and Epifantseva, 2002 who study universities or Bertrand, Hallock, and Arnould, 2005 who study hospitals). Nursing homes is an example where a potentially important objective could be considered (Weisbrod and Schlesinger, 1986). Perhaps one would want to compensate a manager of a nursing home based on "trustworthiness," but this is incredibly difficult to measure. Other measures of performance in nonprofits include increased public awareness, cost savings, increased funding (Rocco, 1991), and customer satisfaction (Bailey and Risher, 1996). It is clear from these examples that identifying appropriate measures for the goals and objectives of nonprofits is complicated. 
The work reported in this paper is an attempt to carefully consider how the leaders of labor unions are paid in the United States. Labor unions are particularly interesting because they represent a case where the objectives of the leader and the organization are, perhaps, better defined (and measurable) than in other nonprofit sectors. Clearly, unions are interested in both the level of membership and the level of wages of their members (French, Hayashi, and Gray, 1983) ${ }^{1}$. As described below, we collect data on each and empirically determine their relative importance in an executive compensation empirical specification. This may be a way to consider an implicit objective function for the leader.

The rest of this paper is organized as follows. Section II discusses some previous literature on the compensation of executives in nonprofits and in unions in particular. Section III explores the collection and organization of the data. Section IV reports the main empirical results and Section V offers some concluding comments. We find that there is wide heterogeneity in how labor unions compensate their leaders. Further, the effect of union membership is large and significantly related to the compensation of the union President, with elasticities on the same order of magnitude as the elasticity of compensation with respect to firm market value or the elasticity of compensation with respect to employees for publicly traded firms. Similarly, the average wage of the rank and file union member is related to the pay of union presidents. In the end, both union membership and wages of members are importantly related to the pay of union Presidents.

\section{Previous Work, Econometric Specification, and Issues}

Previous work has shown that one of the strongest correlates of managerial pay in American nonprofits (Hallock, 2002) and for-profit organizations (Lambert, Larker, and Weigelt, 1993;

\footnotetext{
${ }^{1}$ Fiorito, Jarley and Delaney (1995) consider union effectiveness in organizing.
} 
Murphy, 1985) is the size of the organization. Size is believed to have such a high correlation with manager's pay because managers in larger organizations have responsibility for more resources and more people. Although managers of nonprofits are paid considerably less than those in for-profit firms (Hallock, 2002; Preston, 1989), a great deal of this is explained by the size of the organization (measured for example by total assets). However, for organizations of similar size, it has been found that non-equity-based compensation is not particularly different in nonprofit organizations than in for-profit firms (Hallock, 2004) ${ }^{2}$. In addition, Hansmann (1980; 1996) and others outline that nonprofit organizations are not barred from making "profits," but they are barred from distributing the excess funds to those in control of the organization. However, it is possible to compensate managers of nonprofits with incentive-based pay (Steinberg, 1990a; 1990b). "One way to minimize the probability that executives will take actions contrary to the organization's goals is to tie their compensation to measures of their organization's performance" (Ehrenberg and Goldberg, 1977, p. 188). We investigate a variety of issues that have been hallmarks in the study of compensation of managers in for-profit firms including the elasticity of pay to organization size (Rosen, 1992) and the relationship between organization performance and executive pay (Jensen and Murphy, 1990; Tosi, Werner, Katz, and Gomez-Mejia, 2000). As noted above, examining unions provides a unique view on the importance of organization performance, measured as wages of members and membership levels, to the compensation of the top union official ${ }^{3}$.

\footnotetext{
${ }^{2}$ At the same time, equity compensation in for-profit firms is often an important fraction of total compensation.

${ }^{3}$ One referee noted that size is an important proxy for many other factors. We agree with this and further while we agree that size is often (but not always) thought as a control in executive compensation studies, we think it is a bit different here. In particular, in publicly traded firms, although shareholders may be interested in revenue or profit growth or growth in the workforce, they are probably primarily ultimately interested in shareholder returns. However, the "shareholder" analogy in the labor union is, in our minds, the union members. So we feel that it is not unreasonable to consider both changes in membership and changes in average wages of members as important measures of performance. Further, we include the variable of firm assets, which can also be thought of as a control for firm size.
} 
A small set of previous studies have investigated the links between the compensation of union Presidents and certain union characteristics. Each of the studies uses only cross sectional data. We briefly mention six of them here. Bressler (1972) examined the compensation of 97 local union presidents in the construction industry in 1967 by regressing annual compensation of the top official on membership size, total net worth of membership, and the hourly wage rate of workers. He found that all were significantly associated with compensation at the 0.01 confidence level, and concluded that "union officials are not unaffected by the agreements they negotiate" (pg. 49). Ehrenberg and Goldberg (1977) investigated the performance and compensation of the 670 heads of building trade unions in 1971 . They found that the salary of a local business agent of a union is related to the "ability to pay" (defined as total dues and total assets) and to his own bargaining performance (measured by absolute level of wages and relative wages compared to wages in and outside their craft). Sandver (1978) examined 100 large local unions using data from 1962, 1967 and 1973. He found, among other results, that membership was significantly related to the compensation of the head of the unions he examined. Sandver and Heneman (1980) studied the relationship among the top three highest paid officials in the 100 largest national unions in 1962, 1967 and 1973. Among their findings is that there was a stable relationship (over time) between the pay of the top officer and the second two officers, similar to that found in for-profit companies. French, Hayashi and Gray (1983), using data from 1978, showed a relationship between union head's compensation and measures of union financial strength, job complexity (measured with the variables: number of locals, functional specialization of administration, industrial diversity of membership, and geographical dispersion of membership), and tenure in the job. Finally, French (1992) investigated the relationship between power and pay of 136 international unions in 1977 and 108 international unions in 1987. 
French defined power in his analysis by the procedures and structures used by unions to elect its officers. More autocratic structures (indicated by longer presidential terms of office, longer intervals between conventions, the election of presidents at conventions, and the election of the board on an at-large basis) were argued to create more power for union presidents. French found support for the hypothesis that power and pay were positively related.

As previously noted, none of the previous studies on the compensation of union Presidents made use of panel data. On the other hand, we investigated a panel of eight years, from 2000 through 2007. Therefore, one of the issues not addressed in previous studies, that of unmeasured heterogeneity of the organizations themselves, can be addressed in our work.

Our main empirical specification considers the determinants of compensation of the President of the union as follows:

$$
\ln P_{i t}=\beta \ln M_{i t}+\gamma \ln W_{i t}+\theta \ln A_{i t}+\alpha_{i}+\varepsilon_{i t}
$$

where $\mathrm{P}$ is the total compensation of the President of the labor union, $\mathrm{M}$ is total membership in the labor union, $\mathrm{W}$ is the average wage of union members ${ }^{4}$ (defined below), $\mathrm{A}$ is the total assets of the labor unions, $i$ indexes unions, $t$ indexes time, and $\left(\alpha_{i}+\varepsilon_{i t}\right)$ is the composite error term containing possible permanent effects. No doubt, average total compensation of the members (including pensions, benefits etc.) would be a better measure than W. However, we do not have access to such data and assume that pensions and benefits are highly correlated with the wage in these organizations.

Clearly, however, the set of organization characteristics does not fully explain the relationship between compensation and membership and member wages (see the $R^{2}$ values in the OLS specifications below), and therefore, in some specifications, we have chosen to allow for

\footnotetext{
${ }^{4}$ A more complicated specification may replace the average wage of union members with the union wage relative to the non-union wage. We do not explore that in this paper.
} 
the possibility that other characteristics of the Presidents and the unions which have not been included thus far in previous research are confounding our investigation of the link among these key variables.

To help remedy this problem, we make use of the benefits of the panel data. We can assume that the source of the endogeneity arises only through the permanent component of the error term, $\alpha_{i}$, and not through the transitory component, $\varepsilon_{i t}$, then the standard fixed-effects estimation of equation (1) will yield consistent estimates of the parameters. This essentially allows us to control for everything that is fixed with respect to the union over time and look at how changes in performance affect changes in top officer pay within unions over time.

\section{Data}

The data for this paper come from LM-2, LM-3, and LM-4 reports filed by each labor organization from $2000-2007$ (inclusive) ${ }^{5}$ that is subject to the Labor-Management Reporting and Disclosure Act (LMRDA), the Civil Service Reform Act (CSRA), and the Foreign Service Act (FSA). The forms disclose a common set of information for all labor unions. Individual data include information such as liabilities, loans, mortgages, dividends, rents, gifts and grants, investments, members of the unions, total dues paid, and compensation of the president ${ }^{6}$. We focus on only a sub-set of the information in the LM-2, LM-3, and LM-4 forms. In all, we study 75,717 organization-years of data for 15,942 unique organizations.

We also categorize labor unions as "International," "Intermediate" or "Local” based on the United States Department of Labor Office of Labor-Management Standards' classification.

\footnotetext{
${ }^{5}$ LM-2, LM-3, and LM-4 data are actually available back to 1959 (the date of the passage of the Labor-Management Reporting and Disclosure Act) on microfilm. We are in beginning stages of collecting data from years prior to 2000. ${ }^{6}$ It may be possible that the president of a specific union in our data also receives pay from another source (or union). Our data are unable to detect this.
} 
International unions are the highest branch of a union representing workers in the United States and Canada, intermediate unions are the administrative structures situated between the international union headquarters and the locals that represent workers in a number of different locals based on geography, industry, sector, etc. ${ }^{7}$, and local unions are the lowest branch of the international union representing workers at a particular plant or in a particular geographic area (Chaison, 2006). Much of the analysis below will be done separately for each of these three categories of labor unions.

We begin by considering summary statistics for only international unions in Table 1a. It is clear from the table that the average (nominal) union president compensation over time in these data is $\$ 141,859$, with a median of $\$ 112,235$. Figure 1 shows that this average increased considerably over time (from $\$ 111,211$ in 2000 to $\$ 213,391$ in 2007). The average international union had 108,848 members. The median number of members is much smaller $(11,642)$ due to the fact that some of the international unions are so large. The average level of assets for the international unions over this time is $\$ 36.4$ million and the total annual dues is $\$ 17.3$ million.

We also created an estimate of the average union member wage,

$$
\mathrm{W}=(\mathrm{D} / 0.015) / \mathrm{M}
$$

where $\mathrm{D}=$ total annual dues of the union, $\mathrm{M}$ is the total union's membership, and we assume that $1.5 \%$ of the union members' pay is contributed to the labor union as dues. ${ }^{8}$ Using the formula in equation (3), we computed that the average member of an international labor union during this

\footnotetext{
${ }^{7}$ For example, the Steelworkers of America has 12 different districts that are arranged geographically and also have two different industry sections, i.e. the Rubber and Plastic Industry Conference and the Aluminum, Brick, and Glass Workers Division (Chaison, 2006, pg. 37).

${ }^{8}$ See Rasian (1983) for further discussion of the appropriateness of the assumption that union members pay, on average, between $1.13 \%$ and $1.6 \%$ of their wages in union dues. We study the robustness of our " $1.5 \%$ assumption" to our results below.
} 
time earned $\$ 42,111^{9}$. Tables $1 \mathrm{~b}$ and $1 \mathrm{c}$ report summary statistics for intermediate and local labor unions, respectively. There are clearly substantially more intermediate union-years of data in our intermediate sample $(3,934)$ than international $(362)$. There are still more local $(71,397)$. The tables clearly show that local unions pay their presidents substantially less than and are smaller than (in terms of assets and membership) intermediate unions, which are substantially smaller than international unions. However, the estimate for the average wage of intermediate union members is substantially higher than the average member wage of locals and internationals. As noted above, this number is an estimate, and the anomaly comes from the fact that there are small numbers for members in the intermediate unions.

\section{Empirical Results}

As is clear from equation (1) we are interested in testing whether membership and average wages of members are two primary goals of labor unions. If the union wants to align the interests of its leader with that of its membership, then it seems reasonable that these two measures would be related to the pay of the head of the union. In addition, we include a measure of organization size (total assets) as this may represent a union's ability to increase membership and wages.

To begin, consider Figure 2, which plots the natural logarithm of the President salary against the natural logarithm of the membership, by year for local unions ${ }^{10}$. Visually, there appears to be a positive relationship between the two. Another measure of organization scale or success could be assets. Figure 3 (organized similar to Figure 2) plots the relationship between the natural

\footnotetext{
${ }^{9}$ One referee noted that the salaries of international union leaders increased 100 percent over the seven year period while the salaries of members remained flat. This is an important point but is aligned with what is going on in forprofit firms. While most worker pay has stayed flat (even adjusting for inflation over the last 30 years, wages at the 75 percentile in the US have been flat), there has been dramatic growth of pay for those earning in the top 5 percent of the wage distribution, including union leaders (Hallock, 2011).

${ }^{10}$ The relationships are very similar for international and intermediate unions and those figures are omitted here for brevity but are available upon request
} 
logarithm of pay of the union Presidents against the natural logarithm of the assets in his or her organization in local unions (Figure 3$)^{11}$. Figure 4 plots the natural logarithm of the unions President's pay against the estimated average union member wage for local unions as computed in equation $(2)^{12}$. It is clear from Figure 4 that the relationship between the President pay and the estimated average wage of the members is less positive than the relationship between union President pay and union membership or between union President pay and union assets.

Table 2 displays results from specifications like that of equation (1) for only international unions. In column (1) we regress the natural log of President compensation on the natural $\log$ of membership and estimate a large and significant elasticity of 0.338 . Column (2) repeats this exercise using the natural log of the estimated average union member wage as the independent variable. The estimated coefficient is much smaller (0.106) but also statistically significantly different from zero ${ }^{13}$. In column (3) we do the analysis again only controlling for the natural log of assets. The estimated elasticity is 0.394 and statistically significantly different from zero. Columns (4) - (7) investigate various combinations of these covariates and include year effects (in column 7). Column (7) suggests that all three independent variables ( $\ln ($ membership), $\ln ($ estimated average wage) and $\ln ($ assets $))$ are significantly related to the compensation of the union President. The $\mathrm{R}^{2}=0.623$ suggests that quite a large fraction of the variation in the pay of the union head is explained by variation in the independent variables, and quite a bit more than in a typical study of for-profit CEO compensation (Murphy, 1999).

\footnotetext{
${ }^{11}$ Again the results are similar in international and intermediate unions and the figures are available upon requests. ${ }^{12}$ Again the results are similar in international and intermediate unions and the figures are available upon requests.

${ }^{13}$ In order to calculate the average member wage, we assumed that wages represent $1.5 \%$ of total dues. In order to check the robustness of this assumption, we repeated the analysis reported in tables 2,3 and 4 by creating a set of 15 new tables ( 5 for each of tables 2, 3 and 4 ). In each of these tables we replaced the assumption of 1.5 percent with, 0.5 percent, 1 percent, 2 percent, 2.5 percent and 3 percent, respectively. We found that the coefficients in tables 2 , 3 and 4 are remarkably consistent with their 5 counterpart tables (available upon request).
} 
A virtue of our data, however, is that we have multiple observations (up to eight each) on the compensation of the President and union characteristics for each union in sample. Column (8) of Table 2 uses this information and controls for organization fixed-effects in the specification of international union president compensation. Column (8) displays the results of equation (2). This produces some interesting results. Even controlling for organization fixed-effects, there is a positive relationship between international President wages and membership and president wages and estimated average worker wages, and both are significantly different from zero at the 0.05 level. That is, even when looking within unions, changes in wages and membership are related to higher levels of pay.

Table 3 repeats the analysis of Table 2 but investigates the compensation of leaders of intermediate unions, rather than international unions. Again, membership, estimated average worker wage and assets are all unconditionally related to the pay of the head of the intermediate union. However, when we control for individual organization fixed-effects (in column 8), the relationship between President pay and membership is positive and significant (estimated elasticity of 0.166 ) and the relationship between President pay and estimated average worker pay is positive and significant (estimated elasticity of 0.180 ). These two elasticities are both significantly different from zero and are statistically indistinguishable from one another.

Table 4 repeats the analysis for the local unions - the group for which we have overwhelmingly more data. Throughout the table, the estimated coefficients are larger than they are in each of the previous tables. When we look within organizations in column (8) of Table 4, we see that the elasticity of President compensation with respect to membership is 0.361 and the elasticity of President pay with respect to the estimated worker wage is 0.282 . Both of these elasticities are significantly different from zero. 
In summary, there seems to be a large and positive relationship between the compensation of the heads of American labor unions and the number of members they have in their union and the estimated average wage of those members. Both variables matter.

\section{Concluding Comments}

A significant body of literature exists on the compensation of managers of firms in the United States (Murphy, 1999), with more recent research conducted on the compensation of managers in nonprofit organizations (Hallock, 2002). However, only a small number of studies have investigated the determinants of pay of top union officials, none examining these determinants longitudinally. We hope this is a useful step in understanding the compensation of the presidents of American labor unions over time.

The argument for the link between executive pay and organizational performance is clear: because executives are in charge of the success of the organization, part of their pay should be contingent on how well the organizations does (Jensen and Murphy, 1990). Similar to for-profit firms, it appears that the pay of union Presidents is tied to the performance of the organization he or she leads. We find that the pay level of top union officials is strongly correlated with the number of members within the union and the estimated wage for those members. Further, we find these results in all three types of unions (international, intermediate, and local), and find these variables are significant when controlling for organization size (with the variable total assets), and even when controlling for organization (with organization fixed-effects). It appears that within unions, as the number of members and average member pay increases, the top union official's pay also increases. The results of our analysis are aligned with past studies conducted with cross-sectional data on the compensation of local union officers (Bressler, 1972; Ehrenberg 
and Goldberg, 1977; Sandver, 1978), and national union officers (French et al., 1983; French, 1992; Sandver and Heneman, 1980).

The emergence of paid full-time union officials continues to be the subject of considerable debate (French, 1992). Some analysts have argued that this development in labor unions ensures that the rewards of union leaders are tied to the membership's goals (French, 1992; Kochan, 1980). Bok and Dunlop (1970) assert that replacing voluntary leaders with salaried officers has enhanced the effectiveness of collective bargaining and therefore advanced the interests of union members. These authors state: "Union members have doubtless suffered far more from inefficient and unimaginative administration than they have ever lost through corruption and undemocratic processes" (pg. 90). Whereas others, suggested in the quote above, have argued that the transition to full-time paid leadership may reduce the responsiveness of officials to interests of union members and has led to a decline in democratic practices within unions (French et al., 1983; Lipset, 1970). These analysts believe that the compensation of union officials is related to their control over the rank-and-file (French, 1992). The results of our study shed some light on this debate. Our findings suggest that the pay of the union President is significantly related to at least some measures of the performance of the union. In particular, the size of the membership and the average wage of members, are both positive and significantly related to the compensation of the union President. Therefore, it appears the "administrative rationalization," defined as "the making of union decisions through rules, organization and expertness rather than through trial by struggle, ideology and hit-or-miss" (Barbash, 1969, p. 147), may have led to the betterment of the rank-and-file.

Although the results of this study provide strong evidence that the compensation of union Presidents is linked to performance of the union, the findings and interpretations from this study 
must remain tentative. For example, a number of other factors important to the rank-and-file, such as benefits of members, relative wage of members, number of strikes, number of layoffs, etc., might influence the salaries of union presidents and have not been included in the present study.

Prior to this study, little was known regarding the pay of union presidents especially since all of the previous work used cross-sectional data and could not examine changes within unions over time. We hope the findings from this study enhance what we know about compensation in nonprofits and motivate further research in this area. 


\section{References}

Bailey, Sally, and Howard Risher, 1996, "Not-for-profits try out new compensation plans," Compensation \& Benefits Review, 28(3), 47-57.

Barbash, Jack, 1969, "Rationalization in the American Union," in Gerald Somers (Eds.), Essays in Industrial Relations Theory, 147-162, Ames: The Iowa State University Press.

Bebchuk, Lucian and Jesse Fried, 2006, Pay Without Performance: The Unfulfilled Promise of Executive Compensation. Boston: Harvard University Press.

Bertrand, Marianne, Kevin F. Hallock, and Richard Arnould, 2005, "Does managed care change the mission of nonprofit hospitals? Evidence from the Managerial Labor Market," Industrial and Labor Relations Review, 58(3): 494-514.

Bok, Derek and John Dunlop, 1970, Labor and the American Community, New York: Simon \& Schuster.

Bressler, Barry, 1972, "The salaries of union officials with specific reference to the construction industry," Economic and Business Bulletin, 24(3): 46-50.

Chaison, Gary, 2006, “Unions in America. London: Sage Publications.

Ehrenberg, Ronald and Steven Goldberg, 1977, "Officer performance and compensation in local building trades unions," Industrial and Labor Relations Review, 30 (2): 188-196.

Ehrenberg, R., Cheslock, J., \& Epifantseva, J. 2001. Paying Our Presidents: What Do Trustees Value? The Review of Higher Education, 25(1): 15-37.

Fiorito, Jack, Paul Jarley, and John Thomas Delaney, 1995, "National Union Effectiveness in Organizing: Measures and Influences," Industrial and Labor Relations Review, 48(4), 613-635.

French, J. Lawrence, 1992, "The power and pay of international union officials," Journal of Labor Research, XIII(2): 157-172.

French, J. Lawrence, Paul Hayashi, and David Gray, 1983, “The compensation of national union presidents: Moderating effects of union size," Journal of Labor Research, IV(3): 225237.

Hallock, Kevin F., 2002, "Managerial pay and governance in American nonprofits," Industrial Relations, 41(3): 377-406. 
Hallock, Kevin F., 2004, “Managerial pay in nonprofit and for-profit organizations,” In Ronald Riggio and Sarah Smith Orr (Eds.), Improving Leadership in Nonprofit Organizations: 76-101. San Francisco, CA: Josey-Bass.

Hallock, Kevin F., 2011, Pay, Cambridge University Press, forthcoming.

Hansmann, Henry, 1980, “The role of nonprofit enterprise," Yale Law Journal, 89: 835-898.

Hansmann, Henry. 1996, The Ownership of Enterprise, Boston: Harvard University Press.

Jensen, Michael and Kevin J. Murphy, 1990, "Performance pay and top management incentives," Journal of Political Economy, 98: 225-264.

Kochan, Thomas, 1980, Collective Bargaining and Industrial Relations. Homeland, IL: Irwin.

Lambert, Richard A, David F. Larcker, and Keith Weigelt, 1993, "The structure of organizational incentives," Administrative Science Quarterly, 38: 438-461.

Lipset Seymour, 1970, “Trade unions and social structure," In Henry Lansberger (Eds.), Comparative Perspectives on Formal Organizations: 29-46. Boston, MA: Little, Brown, and Company.

Murphy, Kevin J., 1985, "Corporate performance and managerial remuneration: An empirical analysis," Journal of Accounting and Economics, 7(1-3): 11-42.

Murphy, Kevin J, 1999, "Executive compensation," in Orley Ashenfelter and David Card (Eds.), Handbook of Labor Economics, vol. 3B: 2485-2563. Amsterdam: North-Holland.

Oster, Sharon, 1998, "Executive compensation in the nonprofit Sector," Nonprofit Management \& Leadership, 8(3): 207-221.

Preston, Anne, 1989, "The nonprofit worker in a for-profit world," Journal of Labor Economics, 7(4): 438-463.

Raisian, John, 1983, "Union dues and wage premiums," Journal of Labor Research, IV(1): 1-18.

Rocco, James E., 1991, "Making incentive plans work for nonprofits," Nonprofit World, 9(4), 13-15.

Rosen, Sherwin, 1992, "Contracts and the market for executives," In L.Werin and H. Wijkander (Eds.), Main Currents in Contract Economics: 181-211. Oxford, England: Blackwell.

Sandver, Marcus, 1978, "Determinants of pay for large local union officers," Industrial Relations, 17(1): 108-111.

Sandver, Marcus and Herbert Heneman, 1980, "Analysis and prediction of top national union 
officers' total compensation," Academy of Management Journal, 23(3): 534-543.

Steinberg, Richard, 1990a, "Labor economics and the nonprofit sector: A literature review," Nonprofit and Voluntary Sector Quarterly, 19: 151-170.

Steinberg, Richard, 1990b, "Profits and incentive compensation in nonprofit firms," Nonprofit Management and Leadership, 1: 137-152.

Tosi, Henry L., Steve Werner, Jeffrey P. Katz, and Luis R. Gomez-Mejia, 2000, "How much does performance matter? A meta-analysis of CEO pay studies," Journal of Management, 26: 301-339.

Weisbrod, B., \& Schlesinger, M. 1986. Public, private, nonprofit ownership and the response to asymmetric information: The case of nursing homes. In S. Rose-Ackerman (Eds.), The Economics of Nonprofit Institutions: Studies in Structure and Policy: 133-151. New York: Oxford University Press. 
Figure 1. Average Pay of Presidents of International Labor Unions.

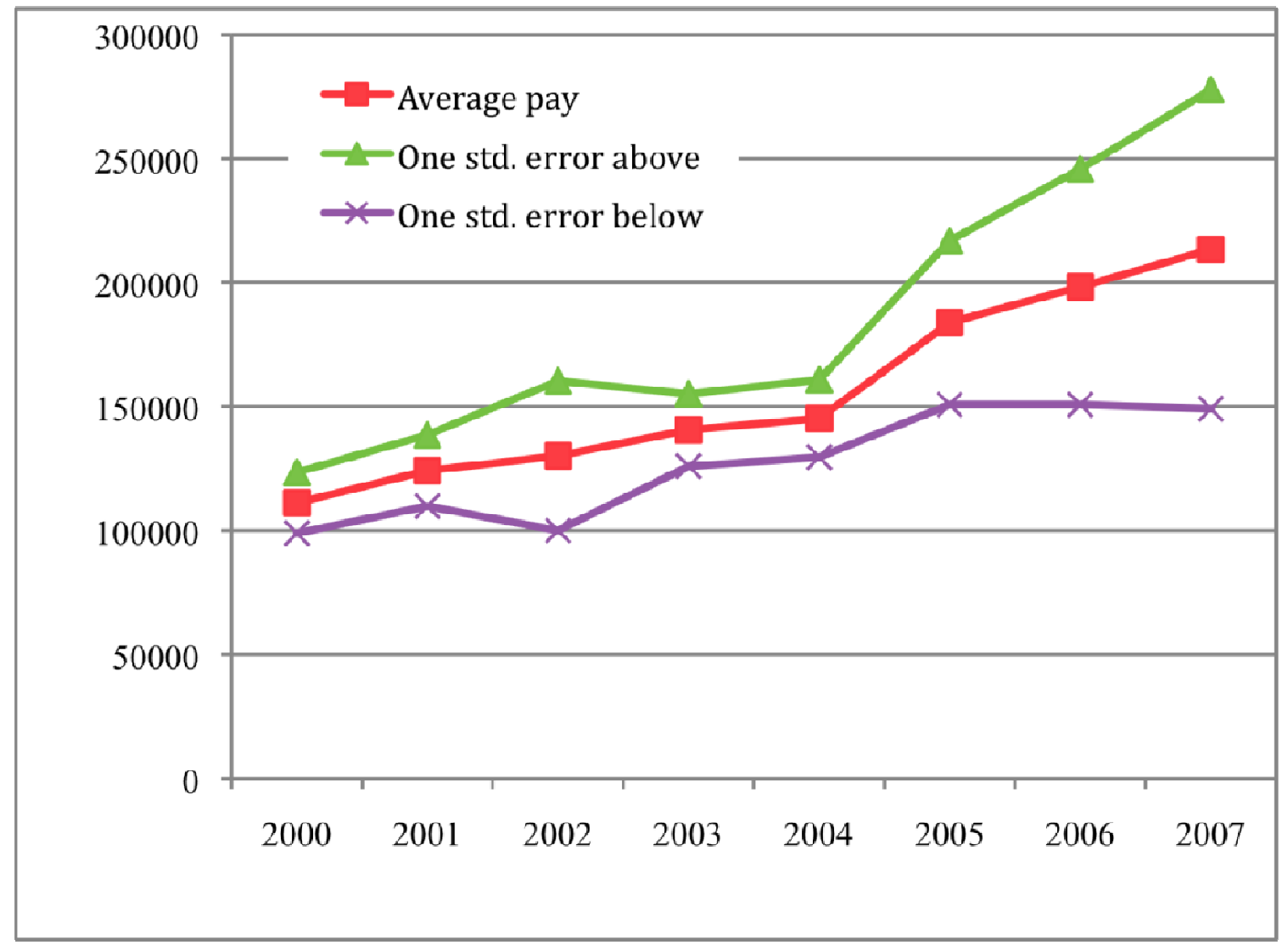


Figure 2.

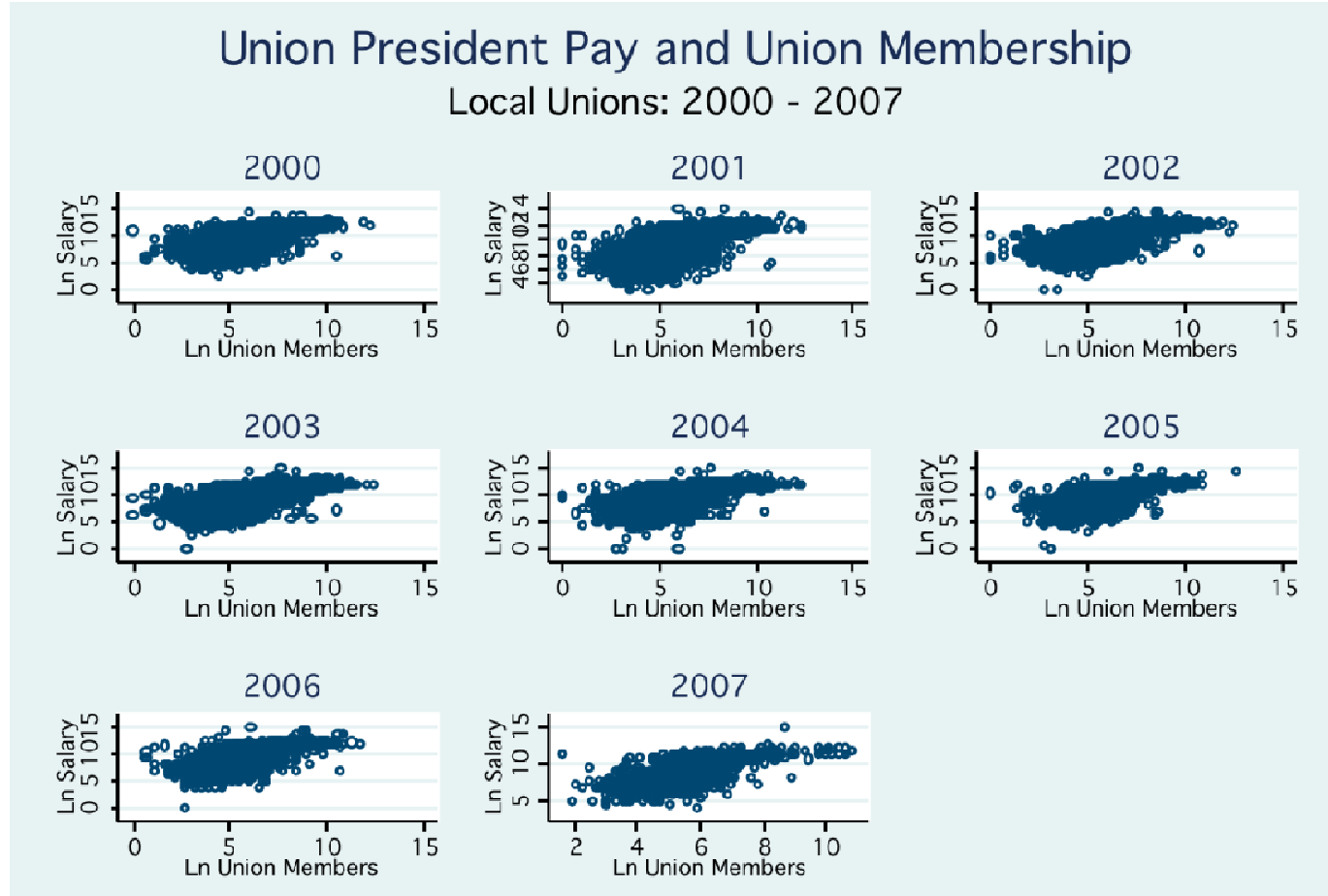

Source: LM-2 Data 
Figure 3.

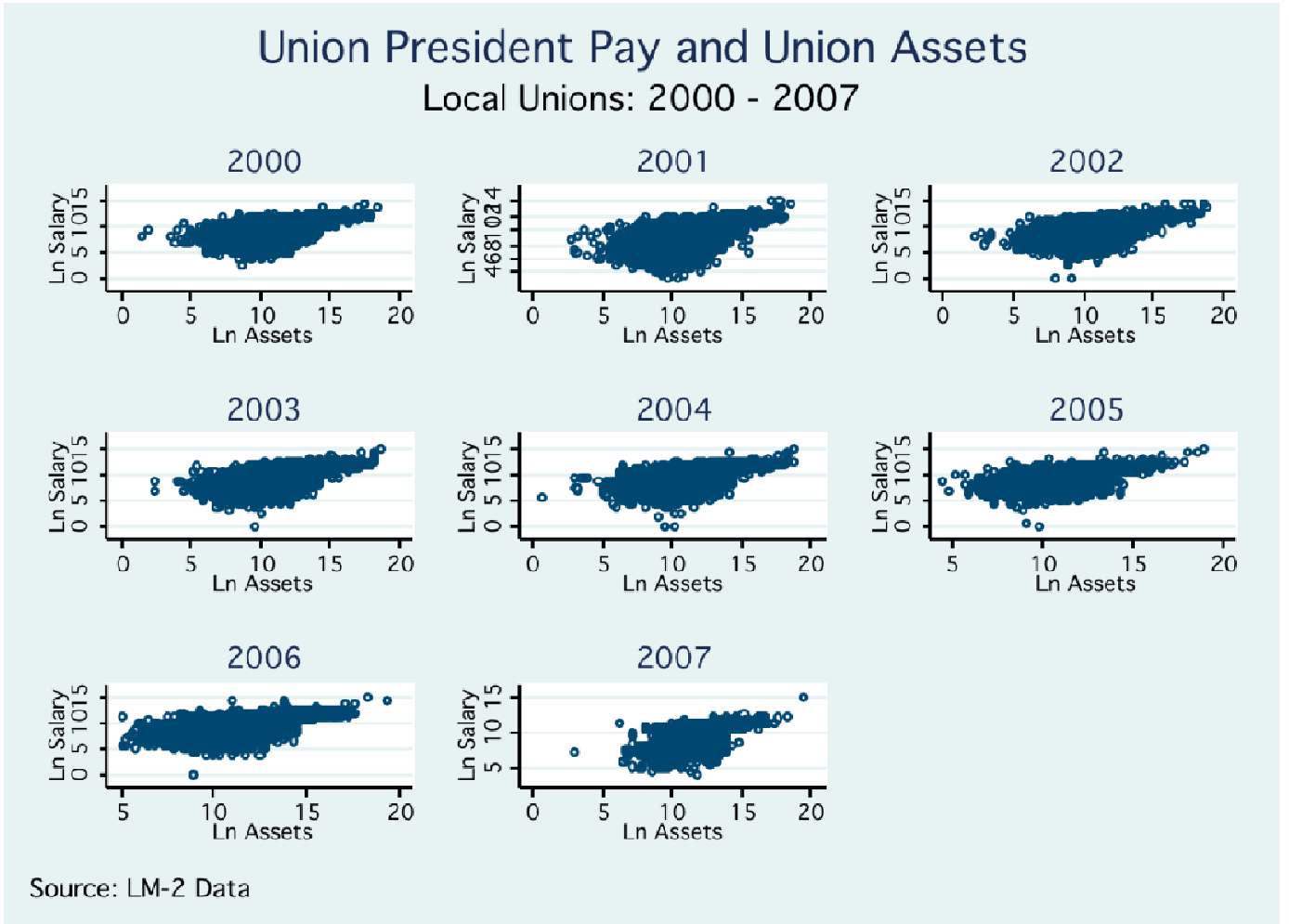


Figure 4.

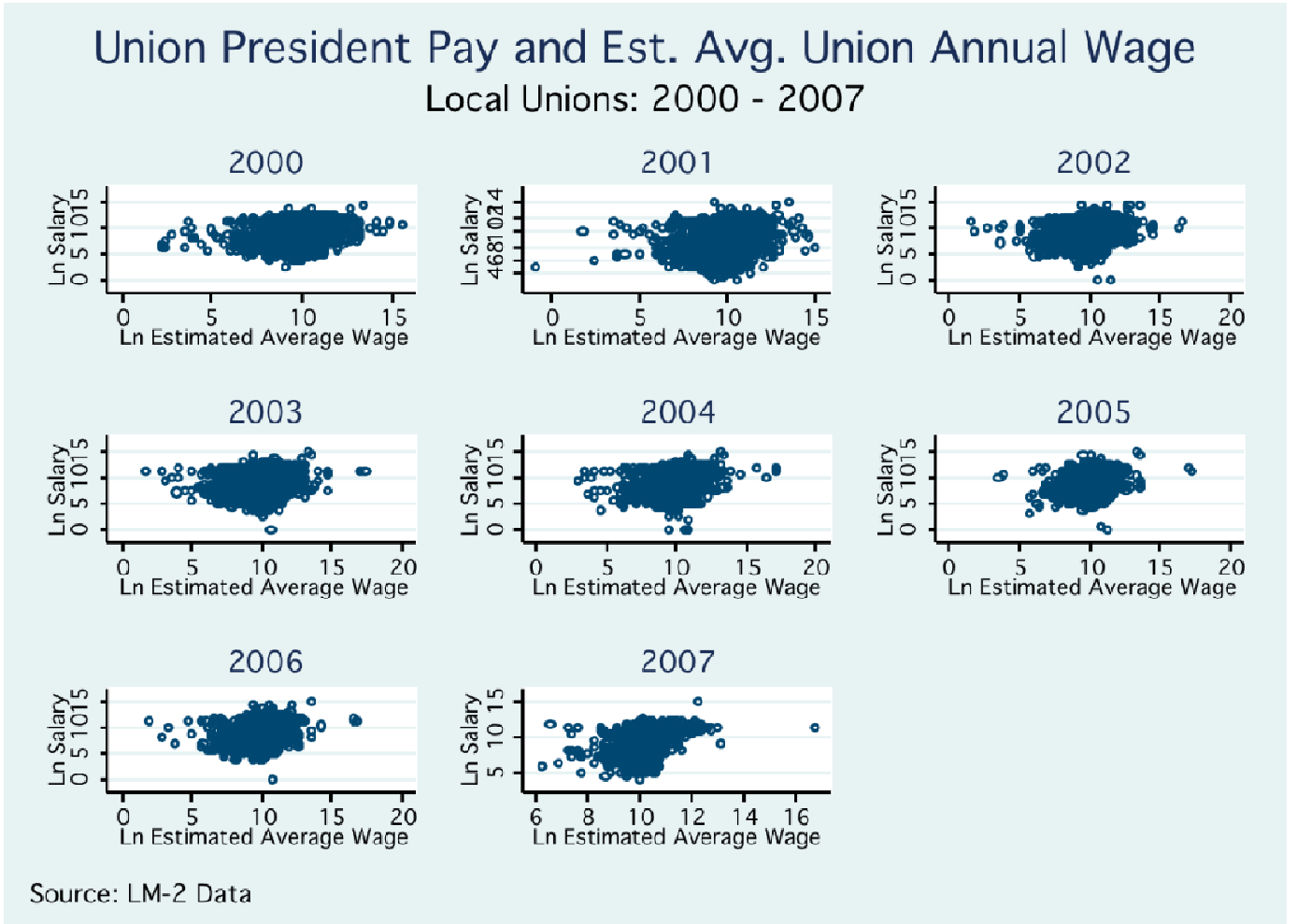


Table 1a. International. Summary Statistics

\begin{tabular}{|c|c|c|c|c|c|c|c|c|c|}
\hline & All Years & 2000 & 2001 & 2002 & 2003 & 2004 & 2005 & 2006 & 2007 \\
\hline President & 141859 & 111211 & 124185 & 130152 & 140557 & 145211 & 183822 & 198270 & 213391 \\
\hline \multirow[t]{2}{*}{ Compensation } & $(137816)$ & $(89529)$ & $(106675)$ & (111803) & $(118382)$ & (126779) & $(151521)$ & $(268800)$ & $(161828)$ \\
\hline & {$[112235]$} & [100629] & [106300] & [109657] & [117611] & [114572] & [131629] & [122927] & [175592] \\
\hline \multirow[t]{3}{*}{ Members } & 108848 & 118496 & 118439 & 110712 & 63771 & 99380 & 183745 & 134966 & 114119 \\
\hline & $(361274)$ & (370923) & $(382702)$ & (1358391) & (127843) & (347853) & (595487) & $(496932)$ & $(205867)$ \\
\hline & [11642] & [8130] & [11894] & [11540] & [11750] & [10782] & [23205] & [13847] & [18519] \\
\hline Estimated Average & 42111 & 36318 & 39636 & 39430 & 38075 & 36687 & 24045 & 94631 & 32472 \\
\hline \multirow[t]{2}{*}{ Member Wage $^{a}$} & $(154831)$ & (143783) & (159392) & $(142516)$ & $(131220)$ & (122368) & $(34302)$ & (297679) & (25097) \\
\hline & [14270] & [12395] & [12747] & {$[14168]$} & [15448] & {$[15255]$} & [15696] & [18277] & [19160] \\
\hline \multirow{2}{*}{$\begin{array}{l}\text { Assets } \\
\text { (in thousands) }\end{array}$} & 36400 & 32600 & 33700 & 33500 & 32400 & 35500 & 45400 & 39000 & 118000 \\
\hline & $\begin{array}{c}(81800) \\
{[4294]}\end{array}$ & $\begin{array}{c}(70000) \\
{[2405]}\end{array}$ & $\begin{array}{c}(71500) \\
{[3856]}\end{array}$ & $\begin{array}{c}(71500) \\
{[5238]}\end{array}$ & $\begin{array}{c}(73100) \\
{[3960]}\end{array}$ & $\begin{array}{c}(78900) \\
{[4216]}\end{array}$ & $\begin{array}{c}(107000) \\
{[10300]}\end{array}$ & $\begin{array}{c}(96500) \\
{[5022]}\end{array}$ & $\begin{array}{c}(206000) \\
{[49300]}\end{array}$ \\
\hline \multirow{3}{*}{$\begin{array}{l}\text { Total Annual Dues } \\
\text { (in thousands) }\end{array}$} & 17300 & 16200 & 17300 & 17500 & 13100 & 17000 & 26200 & 19500 & 31300 \\
\hline & $(45100)$ & $(42800)$ & $(45900)$ & (44700) & $(30600)$ & $(44600)$ & $(68900)$ & $(56800)$ & (48800) \\
\hline & [2180] & [1761] & [2191] & [2545] & [2583] & [2386] & [4162] & [1799] & [10400] \\
\hline $\mathrm{N}$ & 362 & 53 & 55 & 62 & 66 & 66 & 21 & 32 & 7 \\
\hline
\end{tabular}

Note: Standard deviations in parentheses. Medians in brackets.

${ }^{\mathrm{a}}$ Estimated average member wage is defined as $\mathrm{W}=(\mathrm{D} / 0.015) / \mathrm{M}=($ total annual union dues / 0.015) / total union membership 
Table 1b. Intermediate. Summary Statistics

\begin{tabular}{|c|c|c|c|c|c|c|c|c|c|}
\hline & All Years & 2000 & 2001 & 2002 & 2003 & 2004 & 2005 & 2006 & 2007 \\
\hline President & 64270 & 49512 & 58140 & 68777 & 76092 & 62791 & 66240 & 71056 & 52363 \\
\hline \multirow[t]{2}{*}{ Compensation } & (175730) & (43033) & (130421) & (187233) & (319119) & (57551) & (166461) & (145642) & (52363) \\
\hline & [55485] & [47851] & [54477] & [56767] & [56601] & [60648] & [42164] & [53076] & [49915] \\
\hline \multirow[t]{3}{*}{ Members } & 6987 & 6140 & 5988 & 7521 & 7482 & 7710 & 6917 & 7426 & 4934 \\
\hline & (27366) & (22026) & (19470) & (28725) & $(29472)$ & (31627) & (33043) & (30397) & (8853) \\
\hline & [1894] & [1873] & [1905] & [2012] & [1950] & [1912] & [1489] & [1726] & [1712] \\
\hline \multirow{3}{*}{ Member Wage ${ }^{\text {a }}$} & 153966 & 159832 & 158378 & 126585 & 148768 & 172960 & 96264 & 195416 & 159988 \\
\hline & (1200376) & (1564272) & (1340950) & (877089) & (990140) & (1366815) & $(560751)$ & (1293656) & (733777) \\
\hline & [11702] & [10345] & [11991] & [11629] & [11146] & [11958] & [13132] & {$[13778]$} & [12059] \\
\hline \multirow{3}{*}{$\begin{array}{l}\text { Assets } \\
\text { (in thousands) }\end{array}$} & 2021 & 1285 & 1476 & 1843 & 2065 & 2215 & 2742 & 3076 & 2783 \\
\hline & (7723) & (3981) & (4399) & (6667) & (7989) & (8456) & (10600) & (11100) & (11500) \\
\hline & {$[130]$} & [105] & [139] & {$[147]$} & [136] & [149] & {$[98]$} & [113] & {$[165]$} \\
\hline \multirow{3}{*}{$\begin{array}{l}\text { Total Annual Dues } \\
\text { (in thousands) }\end{array}$} & 1408 & 941 & 1064 & 1363 & 1424 & 1581 & 1764 & 2024 & 1682 \\
\hline & (5119) & $(2850)$ & (3109) & (4656) & $(5062)$ & (5693) & (6659) & (7650) & $(6250)$ \\
\hline & {$[179]$} & {$[162]$} & [183] & [186] & {$[185]$} & [204] & {$[145]$} & {$[164]$} & [198] \\
\hline $\mathrm{N}$ & 3934 & 540 & 629 & 656 & 673 & 661 & 253 & 407 & 115 \\
\hline
\end{tabular}

Note: Standard deviations in parentheses. Medians in brackets.

${ }^{\mathrm{a}}$ Estimated average member wage is defined as $\mathrm{W}=(\mathrm{D} / 0.015) / \mathrm{M}$ 
Table 1c. Local. Summary Statistics

\begin{tabular}{|c|c|c|c|c|c|c|c|c|c|}
\hline & All Years & 2000 & 2001 & 2002 & 2003 & 2004 & 2005 & 2006 & 2007 \\
\hline President & 26837 & 22688 & 25530 & 27283 & 28466 & 29161 & 22116 & 29697 & 33511 \\
\hline \multirow[t]{2}{*}{ Compensation } & $(51552)$ & $(36801)$ & $(42121)$ & (44649) & $(51853)$ & $(50176)$ & $(68370)$ & (62114) & (122509) \\
\hline & [6052] & [5298] & [5999] & {$[6528]$} & [6591] & [6674] & {$[4800]$} & [6217] & [8829] \\
\hline \multirow[t]{3}{*}{ Members } & 865 & 799 & 912 & 928 & 907 & 940 & 600 & 745 & 837 \\
\hline & (4054) & (3106) & $(4337)$ & (4481) & (4026) & (4458) & (4738) & (2834) & (3176) \\
\hline & [235] & [235] & [241] & [243] & {$[241]$} & [242] & [182] & {$[230]$} & [254] \\
\hline \multirow{3}{*}{$\begin{array}{l}\text { Estimated Average } \\
\text { Member Wage }^{\mathrm{a}}\end{array}$} & 35226 & 29216 & 30228 & 33568 & 37578 & 39085 & 42854 & 38280 & 46891 \\
\hline & (316499) & (82143) & (57159) & (199482) & (401473) & (397678) & (609844) & (322593) & $(522586)$ \\
\hline & [21465] & [19567] & [20637] & [21513] & {$[22271]$} & [22713] & [21037] & [22830] & [23607] \\
\hline \multirow{3}{*}{$\begin{array}{l}\text { Assets } \\
\text { (in thousands) }\end{array}$} & 558 & 415 & 509 & 569 & 579 & 628 & 518 & 629 & 982 \\
\hline & (3106) & (2017) & (2398) & (2994) & (2770) & (3304) & (3848) & $(3675)$ & (8092) \\
\hline & {$[62]$} & {$[52]$} & {$[61]$} & {$[66]$} & [67] & {$[67]$} & {$[50]$} & [70] & [98] \\
\hline \multirow{3}{*}{$\begin{array}{l}\text { Total Annual Dues } \\
\text { (in thousands) }\end{array}$} & 379 & 310 & 371 & 392 & 407 & 441 & 275 & 369 & 449 \\
\hline & $(1670)$ & (1209) & (1583) & (1601) & (1731) & (2043) & (2047) & (1338) & (1996) \\
\hline & [75] & [70] & [76] & [78] & [79] & [81] & [58] & [76] & [84] \\
\hline $\mathrm{N}$ & 71397 & 10847 & 11782 & 12210 & 12273 & 11937 & 4386 & 6612 & 1350 \\
\hline
\end{tabular}

Note: Standard deviations in parentheses. Medians in brackets.

${ }^{\mathrm{a}}$ Estimated average member wage is defined as $\mathrm{W}=(\mathrm{D} / 0.015) / \mathrm{M}$ 
Table 2. International. "Determinants" of Union President Compensation

Dependent Variable is $\operatorname{Ln}$ (President Compensation)

\begin{tabular}{|c|c|c|c|c|c|c|c|c|}
\hline & (1) & (2) & (3) & (4) & $(5)$ & (6) & $(7)$ & $(8)$ \\
\hline Ln(membership) & $\begin{array}{c}0.338 * * * \\
(0.023)\end{array}$ & & & $\begin{array}{c}0.017 \\
(0.029)\end{array}$ & & $\begin{array}{c}0.099 * * * \\
(0.033)\end{array}$ & $\begin{array}{c}0.100^{* * * *} \\
(0.033)\end{array}$ & $\begin{array}{r}0.204 * * \\
(0.095)\end{array}$ \\
\hline $\begin{array}{l}\text { Ln(avg member } \\
\text { wage) }\end{array}$ & & $\begin{array}{c}0.106 * * * \\
(0.034)\end{array}$ & & & $\begin{array}{c}0.081 * * * \\
(0.021)\end{array}$ & $\begin{array}{c}0.121 * * * \\
(0.025)\end{array}$ & $\begin{array}{c}0.123 * * * \\
(0.025)\end{array}$ & $\begin{array}{c}0.068 * * \\
(0.028)\end{array}$ \\
\hline Ln(assets) & & & $\begin{array}{c}0.394 * * * \\
(0.017)\end{array}$ & $\begin{array}{c}0.382 * * * \\
(0.026)\end{array}$ & $\begin{array}{c}0.391 * * * \\
(0.016)\end{array}$ & $\begin{array}{c}0.320 * * * \\
(0.028)\end{array}$ & $\begin{array}{c}0.320 * * * \\
(0.029)\end{array}$ & $\begin{array}{l}-0.045 \\
(0.046)\end{array}$ \\
\hline Year effects & no & no & no & no & no & no & yes & yes \\
\hline Org effects & no & no & no & no & no & no & no & yes \\
\hline Constant & $\begin{array}{c}8.160 * * * \\
(0.222)\end{array}$ & $\begin{array}{c}10.328 * * * \\
(0.325)\end{array}$ & $\begin{array}{c}5.372 * * * \\
(0.256)\end{array}$ & $\begin{array}{c}5.393 * * * \\
(0.259)\end{array}$ & $\begin{array}{c}4.665^{* * *} * \\
(0.313)\end{array}$ & $\begin{array}{c}4.449 * * * \\
(0.317)\end{array}$ & $\begin{array}{c}4.477 * * * \\
(0.366)\end{array}$ & $\begin{array}{c}9.613 * * * \\
(1.107)\end{array}$ \\
\hline $\begin{array}{l}\text { Adj. } \mathrm{R}^{2} \\
\mathrm{~N}\end{array}$ & $\begin{array}{c}0.371 \\
362 \\
\end{array}$ & $\begin{array}{c}0.023 \\
362 \\
\end{array}$ & $\begin{array}{c}0.605 \\
362 \\
\end{array}$ & $\begin{array}{c}0.604 \\
362 \\
\end{array}$ & $\begin{array}{c}0.619 \\
362 \\
\end{array}$ & $\begin{array}{c}0.628 \\
362 \\
\end{array}$ & $\begin{array}{c}0.623 \\
362 \\
\end{array}$ & $\begin{array}{c}0.954 \\
362 \\
\end{array}$ \\
\hline
\end{tabular}

Note: Standard errors are in parentheses.

$*$ p-value $<.10$

$* * \mathrm{p}$-value $<.05$

$* * * \mathrm{p}$-value $<.01$ 
Table 3. Intermediate. "Determinants" of Union President Compensation

Dependent Variable is Ln(President Compensation)

\begin{tabular}{|c|c|c|c|c|c|c|c|c|}
\hline & (1) & (2) & (3) & (4) & $(5)$ & (6) & (7) & (8) \\
\hline Ln(membership) & $\begin{array}{c}0.285^{* * * *} \\
(0.012)\end{array}$ & & & $\begin{array}{c}0.015 \\
(0.011)\end{array}$ & & $\begin{array}{c}0.479 * * * \\
(0.016)\end{array}$ & $\begin{array}{c}0.478^{* * * *} \\
(0.016)\end{array}$ & $\begin{array}{c}0.166^{* * * *} \\
(0.024)\end{array}$ \\
\hline $\begin{array}{l}\text { Ln(avg member } \\
\text { wage) }\end{array}$ & & $\begin{array}{c}0.308 * * * \\
(0.012)\end{array}$ & & & $\begin{array}{c}0.183 * * * \\
(0.010)\end{array}$ & $\begin{array}{c}0.518 * * * \\
(0.014)\end{array}$ & $\begin{array}{c}0.517 * * * \\
(0.014)\end{array}$ & $\begin{array}{c}0.180 * * * \\
(0.019)\end{array}$ \\
\hline Ln(assets) & & & $\begin{array}{c}0.440 * * * \\
(0.008)\end{array}$ & $\begin{array}{c}0.434 * * * \\
(0.010)\end{array}$ & $\begin{array}{c}0.398 * * * \\
(0.008)\end{array}$ & $\begin{array}{c}0.096 * * * \\
(0.013)\end{array}$ & $\begin{array}{c}0.096 * * * \\
(0.013)\end{array}$ & $\begin{array}{r}-0.013 \\
(0.015)\end{array}$ \\
\hline Year effects & no & no & no & no & no & no & yes & yes \\
\hline Org effects & no & no & no & no & no & no & no & yes \\
\hline Constant & $\begin{array}{c}8.150 * * * \\
(0.088)\end{array}$ & $\begin{array}{c}7.392 * * * \\
(0.110)\end{array}$ & $\begin{array}{c}4.935 * * * \\
(0.102)\end{array}$ & $\begin{array}{c}4.911^{* * *} \\
(0.104)\end{array}$ & $\begin{array}{c}3.772 * * * \\
(0.115)\end{array}$ & $\begin{array}{c}0.853^{* * * *} \\
(0.144)\end{array}$ & $\begin{array}{c}0.683 * * * \\
(0.173)\end{array}$ & $\begin{array}{c}7.556 * * * \\
(0.347)\end{array}$ \\
\hline Adj. $R^{2}$ & 0.130 & 0.150 & 0.416 & 0.416 & 0.464 & 0.562 & 0.562 & 0.930 \\
\hline $\mathrm{N}$ & 3934 & 3934 & 3934 & 3934 & 3934 & 3934 & 3934 & 3934 \\
\hline
\end{tabular}

Note: Standard errors are in parentheses.

$*$ p-value $<.10$

$* *$ p-value $<.05$

$* * *$ p-value $<.01$ 
Table 4. Local. "Determinants" of Union President Compensation

Dependent Variable is Ln(President Compensation)

\begin{tabular}{|c|c|c|c|c|c|c|c|c|}
\hline & $(1)$ & (2) & (3) & (4) & (5) & (6) & $(7)$ & $(8)$ \\
\hline Ln(membership) & $\begin{array}{c}0.897 * * * \\
(0.003)\end{array}$ & & & $\begin{array}{c}0.523 * * * \\
(0.004)\end{array}$ & & $\begin{array}{c}0.686^{* * * *} \\
(0.004)\end{array}$ & $\begin{array}{c}0.688 * * * \\
(0.004)\end{array}$ & $\begin{array}{c}0.361 * * * \\
(0.007)\end{array}$ \\
\hline $\begin{array}{l}\text { Ln(avg member } \\
\text { wage) }\end{array}$ & & $\begin{array}{c}0.647 * * * \\
(0.007)\end{array}$ & & & $\begin{array}{c}0.347 * * * \\
(0.005)\end{array}$ & $\begin{array}{c}0.584 * * * \\
(0.005)\end{array}$ & $\begin{array}{c}0.583^{* * * *} \\
(0.005)\end{array}$ & $\begin{array}{c}0.282 * * * \\
(0.006)\end{array}$ \\
\hline Ln(assets) & & & $\begin{array}{c}0.633 * * * \\
(0.002)\end{array}$ & $\begin{array}{c}0.356^{* * * *} \\
(0.003)\end{array}$ & $\begin{array}{c}0.600 * * * \\
(0.002)\end{array}$ & $\begin{array}{c}0.215^{* * * *} \\
(0.003)\end{array}$ & $\begin{array}{c}0.213^{* * * *} \\
(0.003)\end{array}$ & $\begin{array}{c}-0.034 * * * \\
(0.004)\end{array}$ \\
\hline Year effects & no & no & no & no & no & no & yes & yes \\
\hline Org effects & no & no & no & no & no & no & no & yes \\
\hline Constant & $\begin{array}{c}3.989 * * * \\
(0.019)\end{array}$ & $\begin{array}{c}2.543 * * * \\
(0.072)\end{array}$ & $\begin{array}{c}1.889 * * * \\
(0.026)\end{array}$ & $\begin{array}{c}2.080 * * * \\
(0.024)\end{array}$ & $\begin{array}{c}-1.214 * * * \\
(0.054)\end{array}$ & $\begin{array}{c}-3.079 * * * \\
(0.047)\end{array}$ & $\begin{array}{c}-3.018 * * * \\
(0.055)\end{array}$ & $\begin{array}{c}4.599 * * * \\
(0.085)\end{array}$ \\
\hline $\begin{array}{l}\text { Adj. } \mathrm{R}^{2} \\
\mathrm{~N}\end{array}$ & $\begin{array}{l}0.520 \\
71397 \\
\end{array}$ & $\begin{array}{c}0.101 \\
71397 \\
\end{array}$ & $\begin{array}{c}0.514 \\
71397 \\
\end{array}$ & $\begin{array}{c}0.592 \\
71397 \\
\end{array}$ & $\begin{array}{c}0.542 \\
71397 \\
\end{array}$ & $\begin{array}{c}0.663 \\
71397 \\
\end{array}$ & $\begin{array}{c}0.664 \\
71397 \\
\end{array}$ & $\begin{array}{c}0.942 \\
71397 \\
\end{array}$ \\
\hline
\end{tabular}

Note: Standard errors are in parentheses.

$* \mathrm{p}$-value $<.10$
$* * \mathrm{p}$-value $<.05$
$* * \mathrm{p}$-value $<.01$ 